\title{
CHARACTERIZATION OF SILICA/SILVER-BASED ANTIBACTERIAL LEATHER
}

\author{
Nur Mutia ROSIATI ${ }^{*}$, Fitrilia SILVIANTI ${ }^{2}$, Mustafidah UDKHIYATI ${ }^{1}$ \\ ${ }^{1}$ Department of Leather Processing Technology, Politeknik ATK Yogyakarta, Sewon, Bantul 55281, Yogyakarta, Indonesia, \\ mutia.rosiati92@gmail.com \\ ${ }^{2}$ Department of Rubber and Plastic Processing Technology, Politeknik ATK Yogyakarta, Sewon, Bantul 55281, Yogyakarta, \\ Indonesia
}

Received: 06.02.2020

Accepted: 06.05.2020

https://doi.org/10.24264/Ifj.20.2.2

CHARACTERIZATION OF SILICA/SILVER-BASED ANTIBACTERIAL LEATHER

ABSTRACT. The hydrophilic character of vegetable tanned leather is potentially a medium for bacterial growth. A treatment using an antibacterial agent applies to prevent bacterial growth on it. The vegetable tanned leather in this study was obtained from the tanning of goat skin using mimosa as a tanning agent. The utilization of silica from volcanic ash modified with silver was employed in this study as an antibacterial agent. The functional groups of materials were analysed using FTIR spectrophotometer and evaluated. The results of thermal studies using TG/DTA show that vegetable tanned leather coated with silica (leather@ $\mathrm{SiO}_{2}$ ) and vegetable tanned leather coated with silica/ silver (leather@SiO $/ \mathrm{Ag}$ ) are thermally stable materials. The inhibition zones of Staphylococcus aureus for leather@ $\mathrm{SiO}_{2}$ and leather@ $\mathrm{SiO}_{2} /$ $\mathrm{Ag}$ were larger compared to vegetable tanned leather with inhibition area of $21.25 \pm 0.50 \mathrm{~mm}, 24.80 \pm 1.64 \mathrm{~mm}$ and $11.40 \pm 0.55 \mathrm{~mm}$, respectively. This confirmed the effectiveness of utilization of silica-based volcanic ash and silver as an antibacterial agent.

KEY WORDS: leather, silica, silver, antibacterial agent

\section{CARACTERIZAREA PIELII CU PROPRIETĂȚI ANTIBACTERIENE TRATATE CU SILICE/ARGINT}

REZUMAT. Având în vedere caracterul său hidrofil, pielea tăbăcită vegetal poate fi un mediu propice pentru creșterea bacteriilor. Se poate aplica un tratament care utilizează un agent antibacterian pentru a preveni creșterea bacteriilor pe piele. Pielea tăbăcită vegetal din acest studiu a fost obținută prin tăbăcirea pielii de capră folosind mimosa ca agent de tăbăcire. Silicea din cenușa vulcanică modificată cu argint a fost utilizată în acest studiu ca agent antibacterian. Grupările funcționale ale materialelor au fost analizate folosind spectrofotometrul FTIR și apoi evaluate. Rezultatele studiilor termice efectuate folosind TG/DTA arată că pielea tăbăcită vegetal acoperită cu silice (leather@SiO ${ }_{2}$ ) și pielea tăbăcită vegetal acoperită cu silice/argint (leather@ $\mathrm{SiO}_{2} / \mathrm{Ag}$ ) sunt materiale stabile din punct de vedere termic. Zonele de inhibare ale Staphylococcus aureus pentru leather@SiO și leather@ $\mathrm{SiO}_{2} / \mathrm{Ag}$ au fost mai mari comparativ cu pielea tăbăcită vegetal cu suprafață de inhibare de 21,25 $\pm 0,50 \mathrm{~mm}, 24,80 \pm 1,64 \mathrm{~mm}$ și, respectiv, $11,40 \pm 0,55 \mathrm{~mm}$. Acest lucru a confirmat eficacitatea utilizării cenușii vulcanice pe bază de silice și a argintului ca agent antibacterian.

CUVINTE CHEIE: piele, silice, argint, agent antibacterian

\section{CARACTÉRISATION DU CUIR ANTIBACTÉRIEN TRAITÉ AVEC DE SILICE/D’ARGENT}

RÉSUMÉ. En raison de sa nature hydrophile, le cuir au tannage végétal peut être un environnement approprié pour la croissance des bactéries. Un traitement peut être appliqué qui utilise un agent antibactérien pour empêcher la croissance bactérienne sur la peau. Le cuir au tannage végétal dans cette étude a été obtenu en tannant la peau de chèvre en utilisant du mimosa comme agent de tannage. La silice provenant des cendres volcaniques modifiée par l'argent a été utilisée dans cette étude comme agent antibactérien. Les groupes fonctionnels des matériaux ont été analysés à l'aide du spectrophotomètre FTIR puis évalués. Les résultats des études thermiques utilisant TG/DTA montrent que le cuir tanné végétal traité avec de silice (leather@SiO ${ }_{2}$ ) et le cuir tanné végétal traité avec de silice/argent (leather@SiO $/ \mathrm{Ag}$ ) sont des matériaux thermiquement stables. Les zones d'inhibition de Staphylococcus aureus pour leather@ $\mathrm{SiO}_{2}$ et leather@ $\mathrm{SiO}_{2} / \mathrm{Ag}$ étaient plus grandes par rapport au cuir au tannage végétal avec une surface inhibitrice de $21,25 \pm 0,50 \mathrm{~mm}, 24,80 \pm 1,64 \mathrm{~mm}$ et 11,40 $\pm 0,55 \mathrm{~mm}$. Cela a confirmé l'efficacité de l'utilisation de cendres volcaniques à base de silice et d'argent comme agent antibactérien.

MOTS CLÉS : cuir, silice, argent, agent antibactérien

\footnotetext{
* Correspondence to: Nur Mutia ROSIATI, Department of Leather Processing Technology, Politeknik ATK Yogyakarta, Sewon, Bantul 55281, Yogyakarta, Indonesia, mutia.rosiati92@gmail.com
} 


\section{INTRODUCTION}

The processes of leather tanning play an important role in obtaining the character of the product, especially the tanning process. In general, the skin is tanned using mineral or vegetable tanning agents. Mineral tanning agents that are usually used are chrome compounds derived from $\mathrm{Cr}$ (III) salts. This species of $\mathrm{Cr}$ (III) may be oxidized forming $\mathrm{Cr}(\mathrm{VI})$ which is known to be a hazardous material to the environment. Therefore, the tanning of skin using chrome compounds needs to be minimized.

The alternative tanning process may be conducted using vegetable tanning agents. These vegetable tanning agents are extracted from plants that are known as renewable natural resources. Vegetable tanning agents generally contain a high number of hydroxyl $(-\mathrm{OH})$ groups, increasing the hydrophilicity and the humidity of the tanned leather. As a result, vegetable tanned skin is potentially a good bacterial growth medium. Bacteria that grow on vegetable tanned skin can lead to a disease for consumers. Hence, it is necessary to make an effort to obtain antibacterial tanned skin.

Antibacterial agents such as pentachlorophenol, polyhalogenated phenolic compounds, dimethylfumarate, quaternary ammonium salts, silylquaternary compounds, etc., have been used in leather industry. However, some of them are harmful to human health and the environment [1-3]. Therefore, studies to find alternative antibacterial agents have been widely developed.

Silica is one of the antimicrobial agents which has been studied in several fields [48]. It can be utilized as antibacterial particles or as delivery systems for antibacterial agents $[6,8]$. Various sources of silica have been used as silica precursors, such as tetraethoxysilane (TEOS) [9-11] and water glass [12]. Volcanic ash is solid waste from an eruption that has the potential to be used as a raw material for the preparation of a silica precursor due to its high silica content. Furthermore, volcanic ash of Mount Merapi has been known to contain 51.31\% silica [13]. However, the utilization of silica as an antibacterial agent has a limited effect against bacteria [6]. One attempt to enhance the antibacterial activity of silica is by modification via metal particles $[5,11,14]$. The previous studies found that silver $(\mathrm{Ag})$ can be used as an antibacterial agent in leather [15-17]. Silver has attracted attention due to its excellent antibacterial activity and non-toxic character $[6,15,16]$. Moreover, it has been reported that the attachment of silica-silver for various fields giving good antibacterial effect $[5,9,10,12,16]$. Thus, this study focuses on applying the silicabased coating modified with silver on leather.

\section{EXPERIMENTAL}

\section{Materials and Methods}

\section{Materials}

The materials used for the vegetable tanning process were three pieces of pickled goat skins and mimosa as a tanning agent. Silica was extracted from ash of Merapi Volcano, Yogyakarta, Indonesia using sodium hydroxide. Other chemicals used included sodium formate, naphthalene sulphonate (Coralon OT produced by STAHL), replacement syntan (Tanicor PWB produced by STAHL), sulphited oil (Derminol OCS produced by STAHL) and silver nitrate (Merck).

\section{Methods}

\section{Synthesis of Silica from Volcanic Ash}

The synthesis of silica was employed as conducted by Sudjarwo and Bee (2017) [20]. Merapi Volcano ash was mixed with sodium hydroxide by the ratio $(w / w)$ of $1: 1$. The mixture was heated to $900^{\circ} \mathrm{C}$ in the furnace for 3 (three) hours. Afterward, the solid product was dissolved in water, after which $2 \mathrm{M}$ hydrochloric acid was added. This mixture was stirred for a day then filtered. The filtrate containing silica was used as a material for coating leather.

\section{Coating Leather with Silver Modified Silica}

The pickled goat skins were processed by the vegetable tanning method for insole shoes (Table 1). Two obtained pieces of leather were coated using the impregnation method [21]. One leather was coated by silica while the other one was coated by silica and $\mathrm{AgNO}_{3}$ solution. These coated leathers were dried and stored in closed plastic bags before the treatment for antibacterial activity assays. 
Table 1: The stages of leather preparation process

\begin{tabular}{ll}
\hline Stage Process & Chemical Material (\%) \\
\hline pH Adjustment & $200 \%$ water \\
& $0.1 \%$ Sodium Formate \\
& (60 minutes) \\
& $200 \%$ water \\
Tanning & $5 \%$ Dispersing Agent (Coralon OT) \\
& (30 minutes) \\
& $10 \%$ Mimosa Sul (60 minutes) \\
& $10 \%$ Mimosa (60 minutes) \\
& $10 \%$ Mimosa (60 minutes) \\
& $5 \%$ Tanicor PWB (60 minutes) \\
& \\
Post Tanning & $4 \%$ Derminol OCS (45 minutes) \\
Fatliquoring & $1 \%$ Silica Solution (2 hours) \\
Coating processes & $1 \%$ Formic Acid (45 minutes) \\
Fixation & $1 \%$ AgNO $_{3}$ solution \\
\hline
\end{tabular}

Identification of Functional Groups with Fourier Transform Infrared (FTIR) Spectrophotometry

FTIR spectrophotometry analysis was performed using Shimadzu FTIR Prestige 21. An amount of $2 \mathrm{mg}$ of sample was homogenized with $200 \mathrm{mg}$ of $\mathrm{KBr}$ powder. It was made into a pellet using $2000 \mathrm{psi}$ in pressure. The absorbance of the sample was recorded at a wavenumber range of $400-4000 \mathrm{~cm}^{-1}$.

Thermal Analysis with Thermo-Gravimetry and Differential Thermal Analysis (TG/DTA)

TG/DTA analysis was conducted using Perkin-Elmer under a nitrogen gas flow with a heating rate of $10.00^{\circ} \mathrm{C} / \mathrm{min}$ within the temperature range of $30.00-750.00^{\circ} \mathrm{C}$. About 5 $\mathrm{mg}$ of sample was prepared in aluminium sample holder then heated according to the standard operating above.

\section{Antibacterial Activity Assays}

The bacteria inoculum was prepared by aseptically transferring isolated colonies (Staphylococcus aureus) to the nutrient broth, then incubated during $24 \mathrm{~h}$ at $37 \pm 1^{\circ} \mathrm{C}$. The inoculum was diluted to $0.5 \mathrm{McF}$ arland turbidity standards (corresponding to a concentration of $1.5-3.0 \times 10^{8} \mathrm{CFU} / \mathrm{mL}$ ). For antibacterial activity evaluation purposes, a coated leather sample ( 2 $\mathrm{cm} \times 2 \mathrm{~cm}$ ) was placed on a Petri dish containing $0.5 \mathrm{~mL}$ of the working bacterial dilution in 20 $\mathrm{ml}$ nutrient agar solution. Afterward, the Petri dishes were incubated for $24 \mathrm{~h}$ at $37 \pm 1^{\circ} \mathrm{C}$.
The evaluation of the antibacterial activity was conducted on the presence of an inhibition growth zone around the edges of the tested leather sample.

\section{RESULTS AND DISCUSSIONS}

The tanning process in this study was employed using goat skin as raw material and mimosa as a vegetable tanning agent. Mimosa contains polyphenols that can interact with collagen of goat skin via hydrogen and covalent bonding. The abundance of hydroxyl groups on the vegetable tanned surface makes it a good bacterial growth medium. Therefore, the vegetable tanned leather was coated using silica and silver to give the antibacterial effect on the leather.

The tanning process leads to an increase in weight of leather (Table 2). This indicates the formation of the bond between the tanning agent and goat skin [22]. As can be seen in Table 2, leather@SiO ${ }_{2}$ and leather@SiO $/ \mathrm{Ag}$ show a higher percentage of weight increase compared to vegetable tanned leather. This can be explained by the modification of leather with silica and $\mathrm{Ag}$ that generated the interaction between modifier and leather. 
Table 2: Percentage of weight increase after process

\begin{tabular}{cccc}
\hline Sample & $\begin{array}{c}\text { Weight of pickled } \\
\text { skin }(\mathrm{g})\end{array}$ & Weight of leather (g) & Percentage of increase (\%) \\
\hline Vegetable tanned leather & 398.8 & 458.5 & 14.52 \\
Leather@SiO & 279.6 & 321.3 & 14.90 \\
Leather@SiO,/Ag & 379.8 & 437.5 & 15.19 \\
\hline
\end{tabular}

The silica was obtained from the Merapi volcanic ash which is abundant and unused material. The treatment of volcanic ash was conducted using sodium hydroxide and hydrochloric acid resulting in sodium silicate. Sodium silicate can react with the hydroxyl groups of vegetable tanned leather forming other hydroxyl groups on the coated vegetable tanned leather. The modification of the coating layer was done using silver. The positive charges of silver interacted with negative charges of protonated oxygen resulting in electrostatic interaction. The illustrations of coated vegetable tanned leather surface are shown in Figure 1.

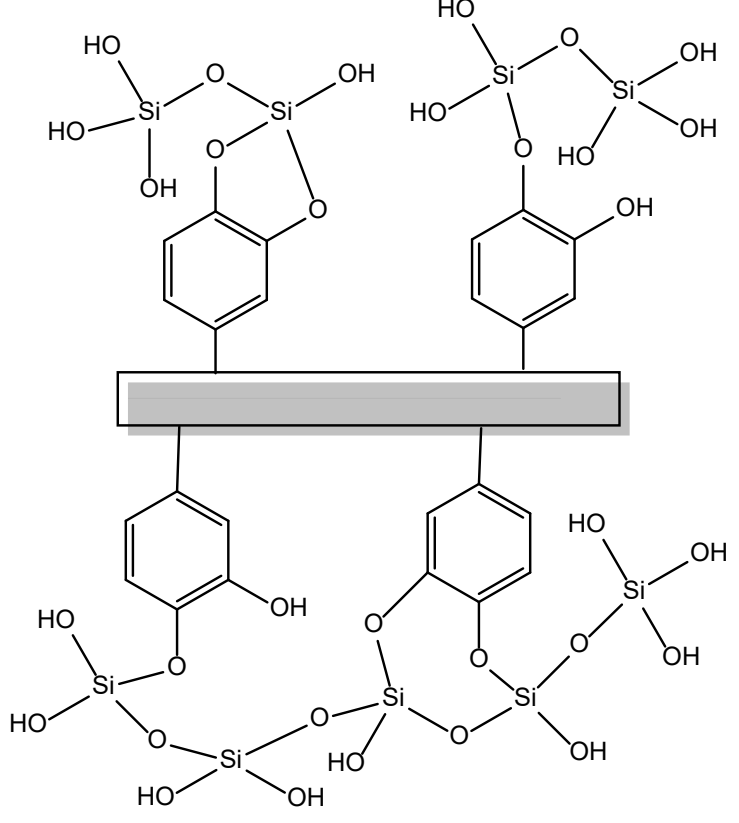

(a)

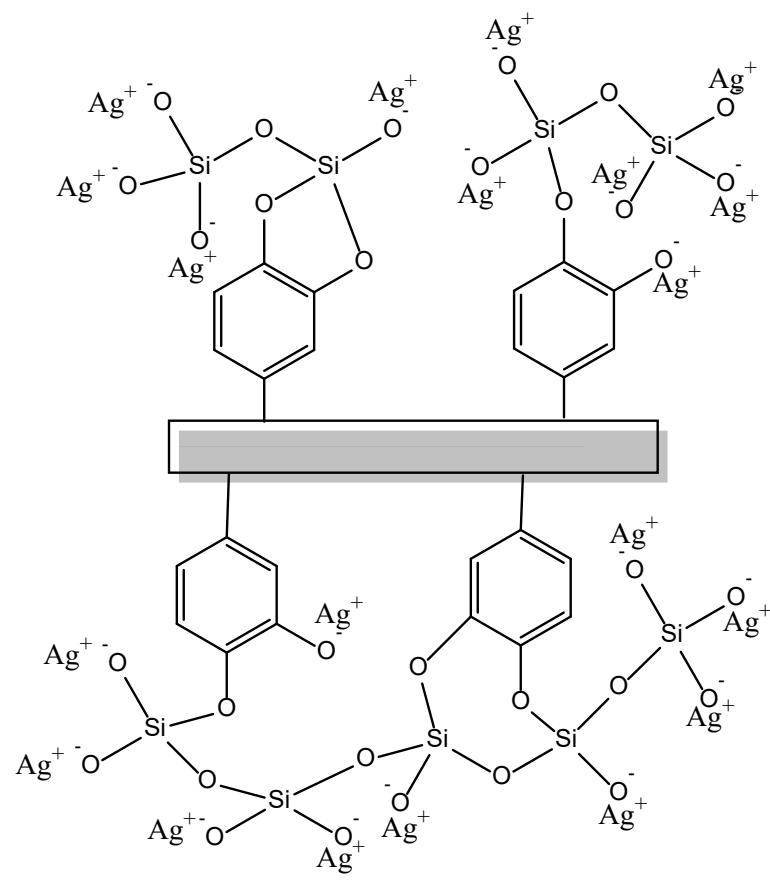

(b)

Figure 1. Interaction model of vegetable tanned leather coated with: (a) silica-based volcanic ash and (b) silica-based volcanic ash/Ag 


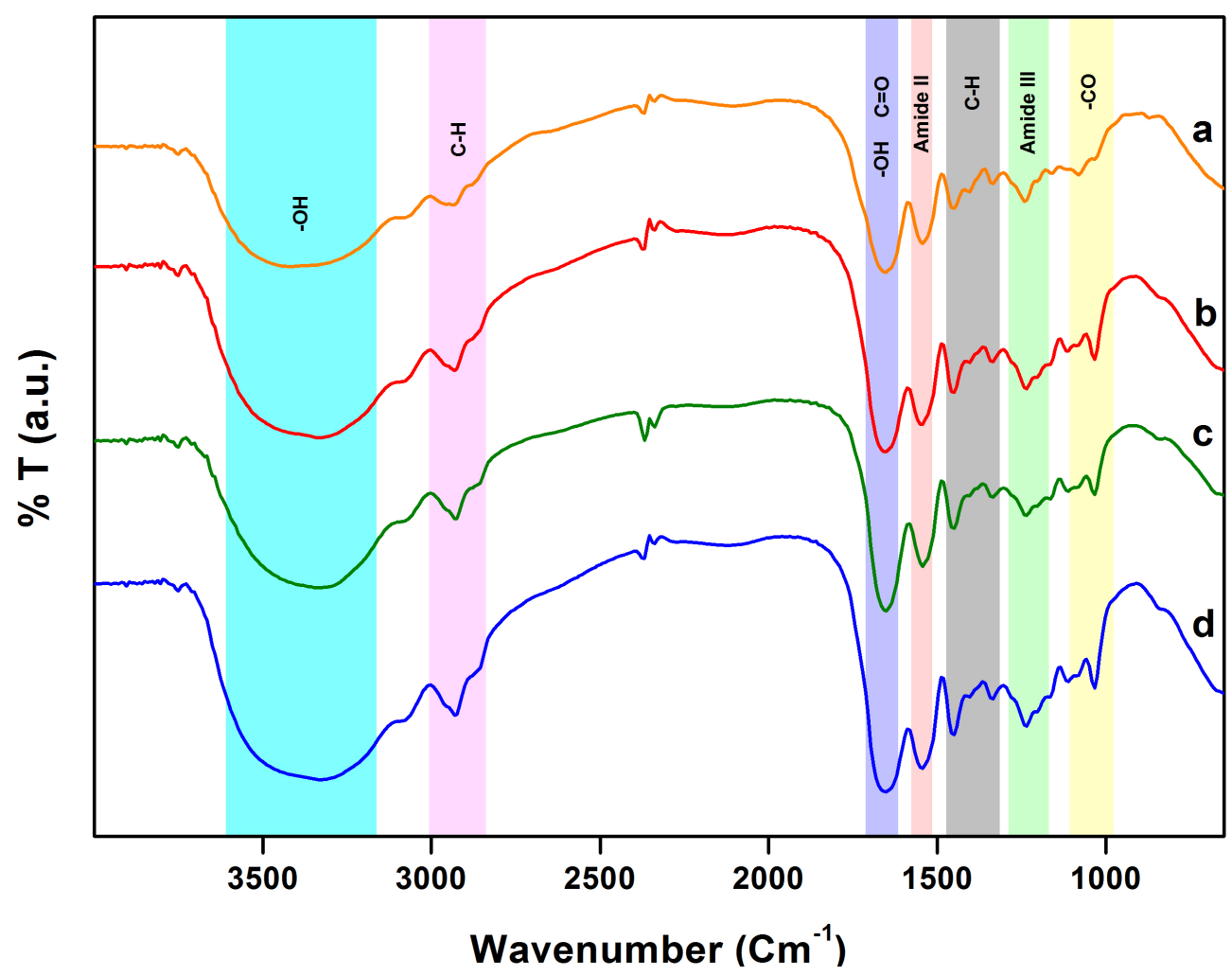

Figure 2. FTIR spectra of (a) pickled goat skin, (b) vegetable tanned leather, (c) leather@SiO $2^{\prime}$ and (d) leather@SiO $2 / \mathrm{Ag}$

The amide groups of leather were identified in several wavelength regions. Amide I band resulted in absorbance at $1651 \mathrm{~cm}^{-1}$ corresponding to $\mathrm{C}=\mathrm{O}$ stretching vibration of pure collagen [23]. This band overlapped with $-\mathrm{OH}$ bending vibration. The absorption band at $1543 \mathrm{~cm}^{-1}$ appeared from the amide II band $[23,24]$. Amide III band is shown between 1234$1242 \mathrm{~cm}^{-1}$ attributing to symmetrical stretching of carboxylate groups [17, 24]. The absorption bands at 1335; 1450 and around 2924-2932 $\mathrm{cm}^{-1}$ appeared as $\mathrm{C}-\mathrm{H}$ bending, $\mathrm{C}-\mathrm{H}$ wagging, and $\mathrm{C}-\mathrm{H}$ asymmetric stretching vibration respectively, verifying the presence of $\mathrm{C}-\mathrm{H}$ bonding in collagen [25-27].

It is shown in the FTIR spectra that the coating with silica does not change the absorption bands of tanned leather. This can be explained by the silica characteristic bands that commonly appeared around 1034-1080 $\mathrm{cm}^{-1}$ and $3400 \mathrm{~cm}^{-1}$ overlapped with $-\mathrm{CO}$ and $-\mathrm{OH}$ stretching bands of tannin [7, 12, 28-31]. However, the attachment of $\mathrm{Ag}$ on leather is not revealed in the FTIR spectra. This phenomenon suggests that no bond occurs between $\mathrm{Ag}$ and the modified leather, indicating that $\mathrm{Ag}$ and modified leather interact electrostatically. It also confirmed that the modification of leather using $\mathrm{Ag}$ does not affect the structure of modified leather [24]. The FTIR spectra revealed no difference in characteristic absorption band between one another. It implies that the modifiers' penetration occurs almost uniformly from the flesh to the grain of the leather.

\section{Stability at Thermal Decomposition}

The TG analysis curves of samples are shown in Figure 3. The thermal degradation of samples showed three stages of weight loss over a temperature range of $30-750^{\circ} \mathrm{C}$. The first stages occurred at $40-90^{\circ} \mathrm{C}$ due to the water content of samples [32, 33]. The second stage ranges between $150-500^{\circ} \mathrm{C}$ and was identified as the decomposition of the organic moiety [34]. The last stage was observed above $500^{\circ} \mathrm{C}$, caused by the weight loss of carbonized residues [33]. 


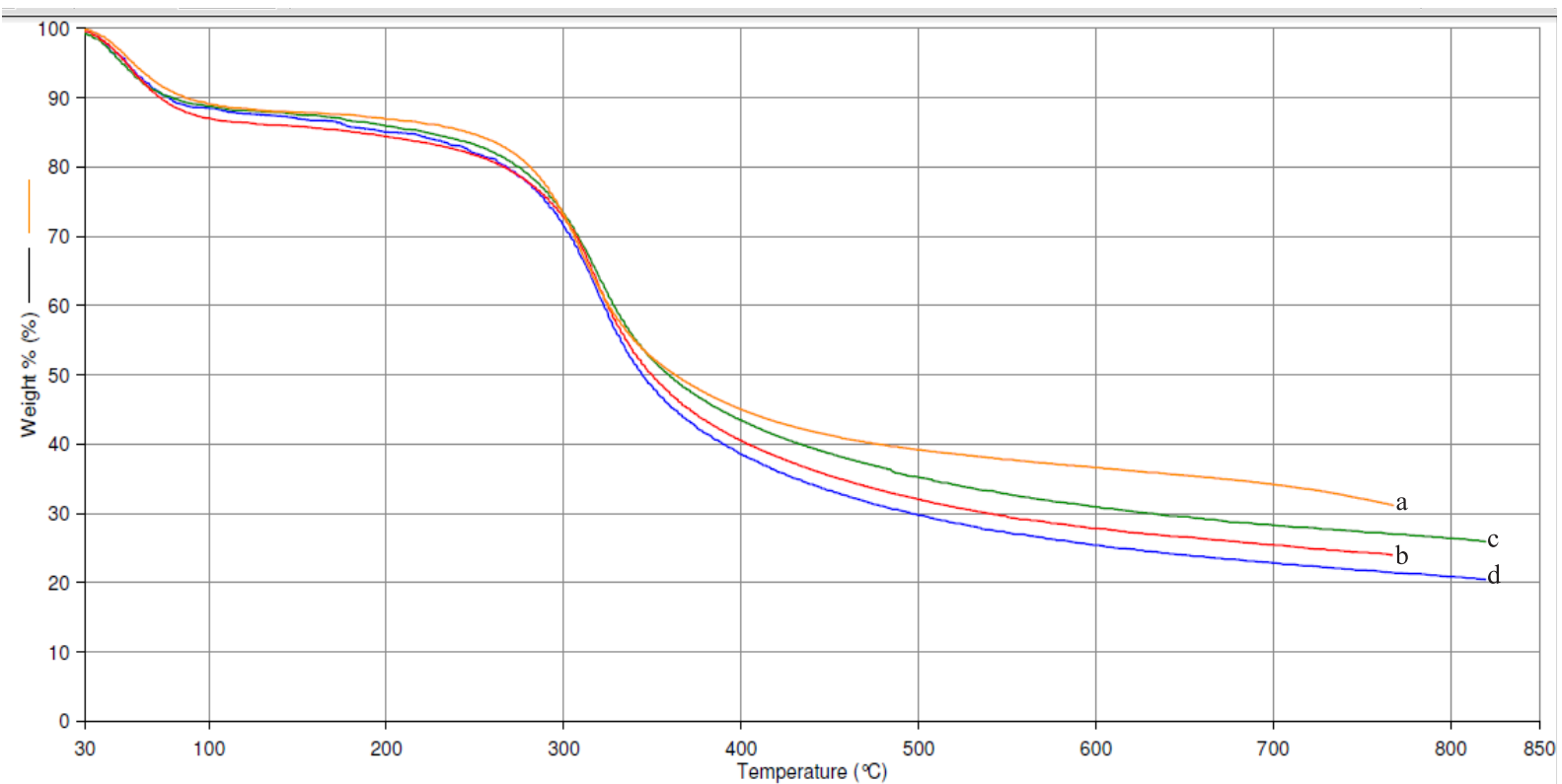

Figure 3. TG curves of (a) pickled goat skin, (b) vegetable tanned leather, (c) leather@SiO ${ }_{2}$ and (d) leather@SiO $2 / \mathrm{Ag}$

Based on the TG analysis, it was confirmed that the weight loss ratio was almost similar for all the samples. The first stage required a higher temperature than the otherstages, corresponding to the decomposition temperature of water. The slight differences in temperature of the second stage were identified for all samples.

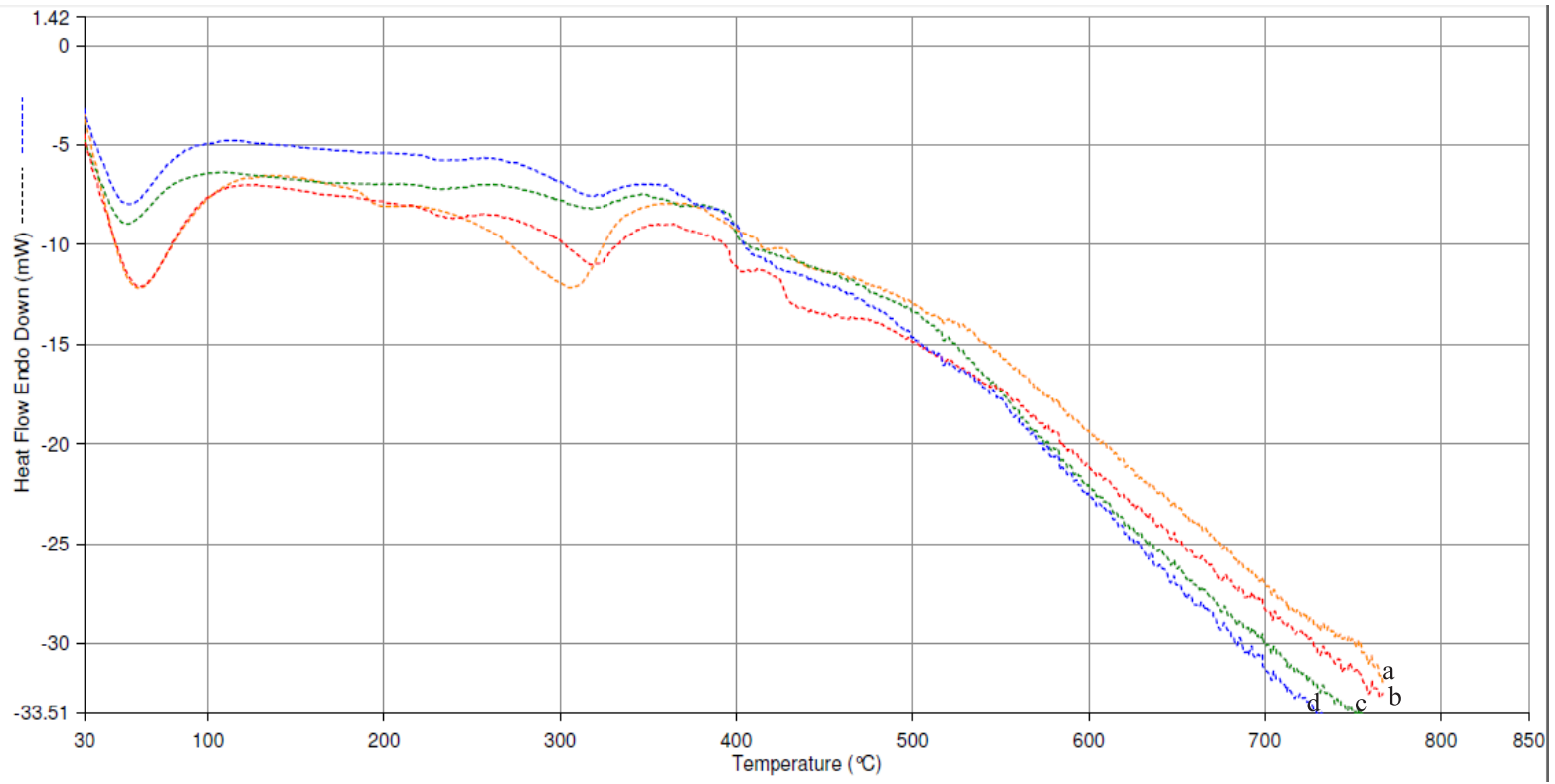

Figure 4. DTA curves of (a) pickled goat skin, (b) vegetable tanned leather, (c) leather@SiO ${ }_{2}$ and (d) leather@SiO $2 / \mathrm{Ag}$

The DTA curves informed two endothermic peaks of samples (Figure 4). The phase change observed at around 56 and $62^{\circ} \mathrm{C}$ corresponds to evaporation of water in pickled skin and coated leathers. The water evaporation temperatures of leather@SiO $\mathrm{S}_{2}$ and that of leather@SiO
$\mathrm{Ag}$ were identified slightly lower than that of pickled goat skin and vegetable tanned leather. The increase of hydroxyl groups in leather@SiO and leather@SiO $/ 2$ Ag can explain this difference in temperature. The endotherm at $300-325^{\circ} \mathrm{C}$ reflects to the release of organic moiety of 
samples. The heat flow of pickled skin and the tanned leather were higher than the silica treated leather, expressing that the coating of silica on leather increases the thermal stability of leather.

\section{Antibacterial Activity}

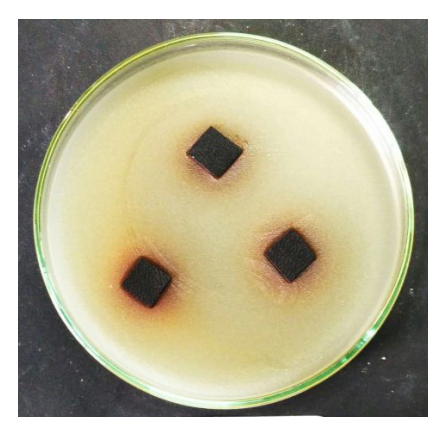

(a)

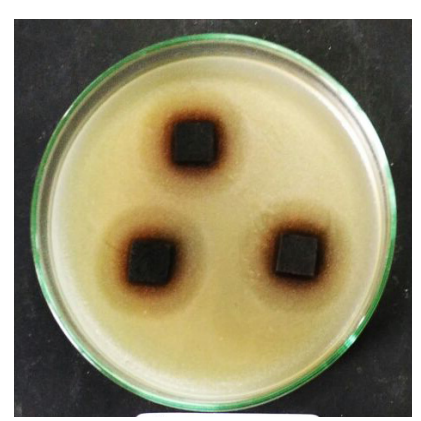

(b)

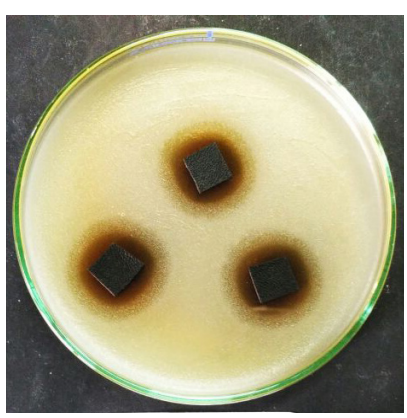

(c)

Figure 5. Staphylococcus aureus inhibition zone of (a) vegetable tanned leather, (b) leather@ $\mathrm{SiO}_{2}$, and (c) leather@SiO $/ 2$ Ag

The antibacterial activity assay was investigated by the agar diffusion method using Staphylococcus aureus to identify the bacteria inhibition zone diameter (Figure 5). The measurement data are written in Table 3. The results imply that the inhibition zones of leather@ $\mathrm{SiO}_{2}$ and leather@SiO$/ 2 / \mathrm{Ag}$ were $21.25 \pm 0.50 \mathrm{~mm}$ and $24.80 \pm 1.64 \mathrm{~mm}$, respectively. This area was larger than the inhibition zone of vegetable tanned leather that is equal to $11.40 \pm 0.55 \mathrm{~mm}$. Anova test shows a significant difference for every data. This confirmed the successful working of silicabased volcanic ash and silver as an antibacterial agent on vegetable tanned leather.

Table 3: Inhibition zone of samples

\begin{tabular}{cc}
\hline Sample & Inhibition Zone $(\mathrm{mm})$ \\
\hline Vegetable tanned leather & $11.40 \pm 0.55$ \\
Leather@SiO & $21.25 \pm 0.50$ \\
Leather@SiO $/ \mathrm{Ag}$ & $24.80 \pm 1.64$ \\
\hline
\end{tabular}

The antibacterial mechanism of silica is different from that of silver. Silica increased the hydrophobicity of vegetable tanned leather, thus reducing bacteria growth on vegetable tanned leather. While silver ions interact with disulfide or sulfhydryl groups of enzymes, causing structural changes leading to disruption of metabolic processes followed by cell death $[35,36]$. Recently, it has been suggested that the antibacterial mechanism of silver nanoparticles may also be related to membrane damage due to free radicals that are derived from the surface of the nanoparticles [37]. This bacterial activity also appeared to be dependent on the size and shape of the silver nanoparticles [38].

\section{CONCLUSIONS}

The utilization of silica-based volcanic ash modified with silver as an antibacterial agent in leather production was investigated in this study. The leather was obtained from the tanning process of goat skin using mimosa as a tanning agent. The antibacterial assay showed that the inhibition zones of Staphylococcus aureus for vegetable tanned leather, leather@SiO 2 and leather@SiO $2 / \mathrm{Ag}$ are $11.40 \pm 0.55 \mathrm{~mm}, 21.25 \pm$ $0.50 \mathrm{~mm}$ and $24.80 \pm 1.64 \mathrm{~mm}$, respectively. It verified the effectiveness of leather coating with silica-based volcanic ash/silver as an antibacterial agent.

\section{Acknowledgements}

This work was funded by Politeknik ATK Yogyakarta through Research Grant of Riset Pembinaan, No. 74.1/SK/SJ-IND.7.7/11/2018. The authors would like to acknowledge Laura Boetje for the valuable proofreading and suggestions, and Wisnu A.A. Sudjarwo for the valuable discussions and providing chemicals. 


\section{REFERENCES}

1. Sirvaityte, J., Siugzdaite, J., Valeika, V., Application of commercial essential oils of Eucalyptus and Lavender as natural preservative for leather tanning industry, Rev Chim, 2011, 62, 9, 885-893.

2. Türkan, M.F., Yapici, A.N., Yapici, B.M., Bilgi, S.D., Assessment of antimicrobial activity of natural leathers treated with Pseudevernia furfuracea (L.) Zopf extracts, Tekstil ve Konfeksiyon, 2013, 23, 2, 176-180.

3. Koizhaiganova, M., Yașa, I., Gülümser, G., Assessment of antibacterial activity of lining leather treated with silver doped hydroxyapatite, Int Biodeterior Biodegradation, 2015, 105, 262-267, https:// doi.org/10.1016/j.ibiod.2015.09.017.

4. Mahltig, B., Fiedler, D., Bottcher, H., Antimicrobial sol-gel coatings, I Sol-Gel Sci Techn, 2004, 32, 219-222, https://doi. org/10.1007/s10971-004-5791-7.

5. Nischala, K., Rao, T.N., Hebalkar, N., Silicasilver core-shell particles for antibacterial textile application, Colloids Surf $B$ Biointerfaces, 2011, 82, 1, 203-208, https:// doi.org/10.1016/j.colsurfb.2010.08.039.

6. Besines, A., Peralta, T.D., Handy, R.D., The antibacterial effects of silver, titanium dioxide and silica dioxide nanoparticles compared to the dental disinfectant chlorhexidine on Streptococcus mutans using a suite of bioassays, Nanotoxicology, 2014, 8, 1, 1-16, https://doi.org/10.3109/17435390.2012.742 935.

7. Maestre-López, M.I., Payá-Nohales, F.J., Arán-Ais, F., Martinez-Sánchez, M.A., Orgilés-Barceló, C., Bertazzo, M., Antimicrobial effect of coated leather based on silver@silicananocomposites: synthesis, characterisation and microbiological evaluation, Journal of Biotechnology and Biomaterials, 2015, 5, 171-181, https://doi. org/10.4172/2155-952X.1000171.

8. Karaman, D.S., Manner, S., Rosenholm, J.M., Mesoporous silica nanoparticles as diagnostic and therapeutic tools: how can they combat bacterial infection?, Ther Deliv, 2018, 9, 4, 1-4, https://doi.org/10.4155/tde-2017-0111.

9. Kawashita, M., Tsuneyama, S., Miyaji, F., Kokubo, T., Kozuka, H., Yamamoto, K., Antibacterial Silver-Containing Silica Glass
Prepared by Sol-Gel Method, Biomaterials, 2000, 21, 4, 393-398, https://doi. org/10.1016/S0142-9612(99)00201-X.

10.Xu, K., Wang, J.X., Kang, X.L., Chen, J.F., Fabrication of antibacterial monodispersed $\mathrm{Ag}-\mathrm{SiO}_{2}$ core-shell nanoparticles with high concentration, Mater Lett, 2009, 63, 31-33, https://doi.org/10.1016/j. matlet.2008.08.039.

11.Berendjchi, A., Khajavi, R., Yazdanshenas, E., Fabrication of superhydrophobic and antibacterial surface on cotton fabric by doped silica-based sols with nanoparticles of copper, Nanoscale Res Lett, 2011, 6, 594, 1-8, https://doi.org/10.1186/1556-276X-6-594.

12.Xing, Y., Yang, X., Dai, J., Antimicrobial finishing of cotton textile based on water glass by sol-gel method, J Sol-Gel Sci Techn, 2007, 43, 187-192, https://doi.org/10.1007/ s10971-007-1575-1.

13.Latif, D.O., Rifa'i, A., Suryolelono, K.B., Chemical characteristics of volcanic ash in Indonesia for soil stabilization: Morphology and mineral content, Int J GEOMATE, 2016, 11, 26, 2606-2610.

14. Wang, Y., Ding, X., Chen, Y., Guo, M., Zhang, Y., Guo, X., Gu, H., Antibiotic-loaded, silver coreembedded mesoporous silica nanovehicles as a synergistic antibacterial agent for the treatment of drug-resistant infections, Biomaterials, 2016, 101, 207-216, https:// doi.org/10.1016/j.biomaterials.2016.06.004.

15. lonita, I., Dragne, A.M., Gaidau, C., Dragomir, T., Collagen fluorescence measurements on nanosilver treated leather, Rom Rep Phys, 2010, 62, 3, 634-643.

16. Pollini, M., Paladani, F., Licciulli, A., Maffezzoli, A., Sannino, A., Nicolais, L., Antibacterial natural leather for application in the public transport system, J Coat Technol Res, 2013, 10,2, 239-245, https://doi.org/10.1007/ s11998-012-9439-1.

17.Velmurugan, P., Lee, S.M., Cho, M.,Park, J.H., Seo, S.K., Myung, H., Bang, K.S., Oh, B.T., Antibacterial activity of silver nanoparticlecoated fabric and leather against odor and skin infection causing bacteria, Appl Microbiol Biotechnol, 2014, 98, 8179-8189, https://doi. org/10.1007/s00253-014-5945-7.

18. Velmurugan, P., Cho, M., Lee, S., Park, J., Bae, S., Oh, B., Antimicrobial fabrication of cotton 
fabric and leather using green-synthesized nanosilver, Carbohydr Polym, 2014, 106, 319-325, $\quad$ https://doi.org/10.1016/j. carbpol.2014.02.021.

19.Liu, G., Gao, H., Li, K., Xiang, J., Lan, T., Zhang, Z., Fabrication of silver nanoparticle sponge leather with durable antibacterial property, J Colloid Interface Sci, 2018, 514, 338-348, https://doi.org/10.1016/j.jcis.2017.09.049.

20.Sudjarwo, W.A.A., Bee, M.M.F., Synthesis of silica gel from waste glass bottles and its application for the reduction of Free Fatty Acid (FFA) on waste cooking oil, AIP Conference, 2017, 1855, 020019, https://doi. org/10.1063/1.4985464.

21.Fernandes, I.P., Amaral, J.S., Pinto, V., Ferreirac, M.J., Barreiroa, M.F., Development of chitosan-based antimicrobial leather coatings, Carbohydr Polym, 2013, 98, 1229-1235, https://doi.org/10.1016/j. carbpol.2013.07.030

22.Kasim, A., Novia, D., Mutiar, S., Pinem, J., Characterization of goat skin on preparation of leather tanned with gambir and properties of leather, Majalah Kulit, Karet dan Plastik, 2013, 29, 1, 01-12, http://dx.doi. org/10.20543/mkkp.v29i1.213.

23.Ramalingam, S., Sreeram, K.J., Rao, J.R., Nair, B.U., Organic Nano-colourants: A self-fixed, optothermal resistive silica supported dyes for sustainable dyeing of leather, ACS Sustain Chem Eng, 2016, 4, 5, 2706-2714, https://doi. org/10.1021/acssuschemeng.6b00218.

24.Lu, Z., Xiao, J., Wang, Y., Meng, M., In situ synthesis of silver nanoparticles uniformly distributed on polydopamine-coated silk fibers for antibacterial application, J Colloid Interface Sci, 2015, 452, 8-14, https://doi. org/10.1016/j.jcis.2015.04.015.

25.Zahran, M.K., Ahmed, H.B., El-Rafie, M.H., Surface modification of cotton fabrics for antibacterial application by coating with AgNPS-alginate composite, Carbohydr Polym, 2014, 108, 145-152, https://doi. org/10.1016/j.carbpol.2014.03.005.

26.Pan, H., Li, G.L., Liu, R.Q., Wang, S.X., Wang, X.D., Preparation, characterization and application of dispersible and spherical nano-SiO ${ }_{2} @$ copolymer_nanocomposite in leather tanning, Appl Surf Sci, 2017, 426, 376-385, https://doi.org/10.1016/j. apsusc.2017.07.106.
27.Nuryono, N., Rosiati, N.M., Rusdiarso, B., Sakti, S.C.W., Tanaka, S., Coating of magnetite with mercapto modified rice hull ash silica in a one-pot process, SpringerPlus, 2014, 3, 515, 1-12, https://doi.org/10.1186/2193-1801-3515.

28.Latif, D.O., Rifa'i, A., Suryolelono, K.B., Chemical characteristics of volcanic ash in Indonesia for soil stabilization: Morphology and mineral content, Int J GEOMATE, 2016, 11, 26, 2606-2610.

29.Djobo, Y.J.N., Elimbi, A., Dika Manga, J., Djon Li Ndjock, I.B., Partial replacement of volcanic ash by bauxite and calcined oyster shell in the synthesis of volcanic ash-based geopolymers, Constr Build Mater, 2016, 113, 673-681, https://doi.org/10.1016/j. conbuildmat.2016.03.104.

30.Nuryono, Rosiati, N.M., Rettob, A.L., Suyanta, Arryanto, Y., Coating of 2-aminobenzimidazole and 1-(o-tolyl)biguanide functionalized silicas on iron sand magnetic material for sorption of [AuCl4] $]^{-}$, Indones J Chem, 2019, 19, 2, 395404, https://doi.org/10.22146/ijc.34653.

31.Chupin, L., Motillon, C., Charrier-El-Bouhtoury, F., Pizzi, A., Charrier, B., Characterisation of maritime, pine (Pinus pinaster) bark tannins extracted under different conditions by spectroscopic methods FTIR and HPLC, Ind Crops Prod, 2013, 49, 897-903, https://doi. org/10.1016/j.indcrop.2013.06.045.

32.Sahu, S., Sahu, U.K., Patel, R.K., Modified thorium oxide polyanilie core-shell nanocomposite and its application for the efficient removal of $\mathrm{Cr}(\mathrm{VI})$, J Chem Eng Data, 2019, 64, 3, 1294-1304, https://doi. org/10.1021/acs.jced.8b01225.

33.Wu, J., Liao, W., Zhang, J., Chen, W.,Thermal behavior of collagen crosslinked with tannic acid under microwave heating, J Therm Anal Calorim, 2019, 135, 2329-2335, https://doi. org/10.1007/s10973-018-7341-5.

34. Yousef, S., Eimontas, J., Strügas, N., Tatariants, M., Abdelnaby, M.A., Tuckute, S., Kliucininkas, L., A sustainable bioenergy conversion strategy for textile waste with self-catalysts using mini-pyrolysis plant, Energy Convers Manag, 2019, 196, 688-704, https://doi. org/10.1016/j.enconman.2019.06.050.

35.Butkus, M.A., Edling, L., Labare, M.P., The efficacy of silver as a bactericidal agent: 
advantages, limitations and considerations for future use, J Water Supply Res T, 2003, 52, 407-416, https://doi.org/10.2166/ aqua.2003.0037.

36.Feng, Q.L., Wu, J., Chen, G.Q., Cui, F.Z., Kim, T.N., Kim, J.O., A mechanistic study of the antibacterial effect of silver ions on Escherichia coli and Staphylococcus aureus, J Biomed Mater Res, 2000, 52, 4, 662-668, https://doi.org/10.1002/1097$4636(20001215) 52: 4<662$ : : A ID JBM10>3.0.CO;2-3.

37.Kim, J.S., Kuk, E., Yu, K.N., Kim, J.H., Park, S.J., Lee, H.J., Kim, S.H., Park, Y.K., Park, Y.H., Hwang, C.Y., Kim, Y.K., Lee, Y.S., Jeong, D.H., Cho, M.H., Antimicrobial effects of silver nanoparticles, Nanomed Nanotechnol, 2007, 3, 1, 95-101, https://doi.org/10.1016/j. nano.2006.12.001.
38.Pal, S., Tak, Y.K., Song, J.M., Does the antibacterial activity of silver nanoparticles depend on the shape of the nanoparticle? A study of the Gram-negative bacterium Escherichia coli, Appl Environ Microbiol, 2007, 73, 1712-1720, https://doi.org/10.1128/ AEM.02218-06.

(C) 2020 by the author(s). Published by INCDTPICPI, Bucharest, RO. This is an open access article distributed under the terms and conditions of the Creative Commons Attribution license (http:// creativecommons.org/licenses/by/4.0/). 